\title{
Myasthenia Gravis with Anti-Muscle-Specific Tyrosine Kinase Antibody during Pregnancy and Risk of Neonatal Myasthenia Gravis: A Case Report and Review of the Literature
}

\author{
Ken-ichi Inoue ${ }^{a}$ Jun Tsugawa ${ }^{b}$ Jiro Fukae ${ }^{a, c}$ Kosuke Fukuhara ${ }^{a}$ \\ Hiroyasu Kawano ${ }^{d}$ Shinsuke Fujioka ${ }^{a}$ Yoshio Tsuboi ${ }^{\mathrm{a}}$ \\ aDepartment of Neurology, Fukuoka University School of Medicine, Fukuoka, Japan; \\ bStroke center, Fukuoka University Chikushi Hospital, Fukuoka, Japan; 'Department of \\ Neurology, Juntendo University Nerima Hospital, Tokyo, Japan; ${ }^{d}$ Department of Pediatrics, \\ Fukuoka University School of Medicine, Fukuoka, Japan
}

\section{Keywords}

Myasthenia gravis · Anti-muscle-specific tyrosine kinase antibody · Pregnancy · Transient neonatal myasthenia gravis

\begin{abstract}
A 31-year-old woman presented with a nasal voice, dysarthria, and upper limb weakness during her first pregnancy. Soon after delivery of her first baby, her symptoms disappeared. At the age of 34 years, during her second pregnancy, her nasal voice re-appeared. After delivery of the second baby, her nasal voice worsened, and bilateral eyelid ptosis and easy fatigability were also evident. She was referred to our hospital. Because of her myasthenic symptoms and anti-muscle-specific tyrosine kinase (MuSK) antibody (Ab)-positive status, she was diagnosed as having myasthenia gravis (MG). Her symptoms were worse than those in her first pregnancy. She was treated with oral steroid and double filtration plasmapheresis. After initiation of treatment, her myasthenic symptoms improved completely. In addition, her baby developed
\end{abstract}




\section{Case Reports in Neurology}

transient neonatal MG (TNMG) on the fourth day after birth and then gradually recovered over 30 days. It should be noted that symptoms of patients with anti-MuSK Ab-positive MG (MuSKMG) can deteriorate during pregnancy, and the babies delivered of patients with MuSK-MG have a high probability of developing TNMG.

(C) 2020 The Author(s)

Published by S. Karger AG, Basel

\section{Introduction}

Myasthenia gravis (MG) is an autoimmune disorder that affects the neuromuscular junction. MG is clinically characterized by weakness and fatigue of the skeletal muscles [1]. Approximately $80 \%$ of patients with MG are positive for anti-acetylcholine receptor (AChR) antibody (Ab), whereas about $5-10 \%$ are positive for anti-anti-muscle-specific tyrosine kinase (MuSK) Ab [2-4]. MG tends to occur in young women (aged <40 years) [1]. Therefore, since this corresponds to the age of pregnancy and childbirth, safe treatment of their MG is needed. In general, there is a $40 \%$ chance of exacerbation of MG during pregnancy and an additional $30 \%$ risk in the puerperal period [5]. On the other hand, pregnancy in patients with anti-MuSK Ab-positive MG (MuSK-MG) has rarely been reported [2-4, 6-10], and the association between MG and pregnancy has not been clarified. The case of a patient with MuSK-MG whose symptoms repeatedly worsened during pregnancy is presented.

\section{Case Report}

\section{Mother}

A 31-year-old woman became pregnant for the first time. In the twentieth week of her pregnancy, she developed dysarthria with a nasal voice for 2 weeks. At 28 weeks of pregnancy, she was not able to lift heavy objects because of bilateral upper limb proximal fatigable weakness. After delivery of her first baby, her symptoms improved. At the age of 34 years, she became pregnant with her second baby. At 12 weeks of pregnancy, she again developed dysarthria with a nasal voice. After caesarean section (CS) delivery at 37 weeks of pregnancy, her nasal voice deteriorated, and bilateral eyelid ptosis and easy fatigability were also evident 2 weeks after the delivery. She was referred to our hospital for neurological evaluation 3 weeks after delivery. She had bilateral eyelid ptosis and double vision due to bilateral abduction limitation. She had a nasal voice. Her muscle strength of the neck and proximal upper limbs were weakened, with diurnal fluctuation. Her blood tests including complete blood count, biochemical tests, and thyroid function were within normal limits. Anti-nuclear Ab, anti-ribonucleoprotein $\mathrm{Ab}$, anti-SS-A Ab, anti-SS-B Ab, proteinase 3-anti-neutrophil cytoplasmic Ab (ANCA), and myeloperoxidase-ANCA were negative. The anti-AChR Ab level was $0.4 \mathrm{nmol} / \mathrm{L}$ (normal range, $<0.2 \mathrm{nmol} / \mathrm{L}$ ), and the anti-MuSK Ab level was $116 \mathrm{nmol} / \mathrm{L}$ (normal range, $<0.05$ $\mathrm{nmol} / \mathrm{L}$ ). Fasciculation appeared in her face and all four limbs after injection of $6 \mathrm{mg}$ edrophonium chloride, indicating hypersensitivity of the neuromuscular junction, previously reported as commonly seen in patients with MuSK-MG [11]. The ice pack test was positive. Repetitive nerve stimulation of the facial nerve at $3 \mathrm{~Hz}$ did not show waning. Gadolinium-enhanced thoracic CT showed no thymoma in the mediastinum. Respiratory function tests showed that the 


\section{Case Reports in Neurology}

percent vital capacity (\%VC) was mildly decreased to $76.3 \%$. She was diagnosed with MG, because she fulfilled the Myasthenia Gravis Foundation of America (MGFA) clinical classification of IIb. She was started on oral prednisolone $10 \mathrm{mg}$ /day every other day and titrated up to a dose of $30 \mathrm{mg} /$ day (Fig. 1a). On day 21 after starting treatment, she showed some improvement in her symptoms, but her nasal voice had not improved much, and her \%VC was still decreased at $74.6 \%$. On day 28, double filtration plasmapheresis (DFPP) was performed for 5 days; her nasal voice improved, and her \%VC increased to $85.3 \%$. She was discharged on day 40. Three weeks later, anti-MuSK Ab decreased to $10.1 \mathrm{nmol} / \mathrm{L}$, and anti-AChR Ab disappeared $(<0.2 \mathrm{nmol} / \mathrm{L})$. After discharge, the prednisolone dosage was tapered; 15 months later, the dosage was $2 \mathrm{mg} /$ day, and no recurrence of symptoms was seen.

\section{Baby's Condition}

Her baby was safely delivered by CS at 37 weeks of pregnancy. The Apgar score was 8 at $1 \mathrm{~min}$ and 9 at $5 \mathrm{~min}$. Birth length was $48.7 \mathrm{~cm}$, and weight was 2,617 g. Four days after birth, cyanosis appeared when the baby cried, and he developed retractive breathing due to vocal cord paralysis, as seen on endoscopy (Fig. 1b). His serum anti-AChR Ab level was $<0.2 \mathrm{nmol} / \mathrm{L}$, and the anti-MuSK Ab level was $19.6 \mathrm{nmol} / \mathrm{L}$. He was diagnosed as having transient neonatal MG (TNMG). He was started on oxygen through a nasal tube. He then gradually improved with only supportive treatment with nasal high-flow therapy and oxygen inhalation. At 45 days after birth, the anti-MuSK Ab level was decreased to $0.69 \mathrm{nmol} / \mathrm{L}$.

\section{Discussion}

The present patient was not diagnosed with MuSK-MG during her first pregnancy because her symptoms disappeared spontaneously in the postpartum period. However, her symptoms recurred during her second pregnancy and persisted after delivery, leading to the diagnosis of MG. Treatment with oral steroid therapy and DFPP relieved her symptoms. Her second baby needed intensive care for respiratory impairment due to TNMG. Both the patient and her baby had good clinical outcomes; however, earlier diagnosis is needed to avoid serious conditions such as MG crisis during pregnancy. One noteworthy point is that her first symptom appeared during pregnancy. Eight cases of MuSK-MG with pregnancy have been previously reported (Table 1) [2-4, 6-10]. Similar to the present patient, 6 of 8 patients were first diagnosed with MuSK-MG during pregnancy or the puerperal period. Most of these patients, were delivered by CS, probably due to myasthenic symptoms of the mother. Some of these patients had miscarriages, presumably due to myasthenic symptoms of both the mothers and the babies. These results suggest that female patients with MuSK-MG may have a chance to be diagnosed during pregnancy, and these patients may need to be delivered by CS because of their uncontrolled MG symptoms. It is important to observe symptoms carefully and perform plasma exchange if necessary without delay for symptom control of pregnant MuSK-MG patients, as Kanzaki and Motomura [8] mentioned in their case report. Thus, if the patient develops myasthenic symptoms during pregnancy, anti-MuSK Ab should be evaluated in the early phase.

In terms of TNMG, the present patient's second baby developed bulbar and respiratory symptoms a couple of days after delivery, and anti-MuSK Ab was found in his serum. It is thought that anti-MuSK Ab transferred from the mother through the placenta was the cause 
of the TNMG. Previous studies reported that TNMG could occur in $10-15 \%$ of cases delivered of MG patients overall $[2,3,9]$. The incidence rate of TNMG from MuSK-MG mothers has never been reported. Previous reports, including the present case, show that 7 of 8 babies developed TNMG $[2,3,6-10]$, indicating that the incidence rate of TNMG from MuSK-MG mothers may be much higher than that of anti-AChR Ab-positive MG (AChR-MG) mothers. In the present case, the patient's second baby improved with oxygen, but there were some cases who needed ventilation and intravenous immunoglobulin therapy $[2,7]$. Thus, it is important to recognize the higher possibility of TNMG if the mother develops MG, and the baby's condition needs to be carefully observed for at least 1 week after delivery.

In general, there is a $40 \%$ chance of exacerbation of MG during pregnancy and an additional 30\% risk during the puerperal period [5]. On the other hand, as in the present case, 5 of 8 MuSK-MG patients worsened during pregnancy [4, 7-10]. These findings suggest that MuSKMG patients are more likely to have exacerbations during pregnancy than AChR-MG patients. Anti-MuSK Ab is classified as IgG4 subclass, whereas anti-AChR Ab is classified as IgG1 and IgG3 [1]. The MG patients carrying anti-MuSK Ab show a tendency towards higher serum levels of IL-4 and IL-10 [12]. Furthermore, a previous in vitro study demonstrated that MuSKimmunized mice had significantly higher levels of IL-4 and IL-10 than those of Freund's complete adjuvant-immunized mice [13], suggesting that IL-4 and IL-10 might play an important role in producing anti-MuSK Ab. During pregnancy, it is known that cytokine levels change for placentation, hCG release, and differentiation. Levels of IL-4 increase throughout normal pregnancy, and levels of IL-10 are increased during the first and second trimesters of pregnancy [14]. IL-10 can act directly on B cells to upregulate IL-4-induced production of IgG4 [15]. Changes in these cytokine levels during pregnancy may raise the anti-MuSK Ab titres.

In conclusion, this case report highlights the fact that female MuSK-MG patients can develop exacerbations during pregnancy, and the baby delivered of a MuSK-MG mother has a high probability of developing TNMG.

\section{Statement of Ethics}

The patient provided oral informed consent for publication of this paper.

\section{Disclosure Statement}

The authors declare no conflict of interest.

\section{Funding Sources}

The authors did not receive any external funding. 


\section{Author Contributions}

Ken-ichi Inoue and Jiro Fukae were the patient's primary physicians, and both performed the review and primary composition of the manuscript. Hiroyasu Kawano was the baby's primary physician. Jun Tsugawa, Shinsuke Fujioka, and Kosuke Fukuhara helped refine the manuscript. Yoshio Tsuboi was involved in the planning and guidance of the written manuscript. All authors were equally involved in the medical management of the patient and approved the final version of the manuscript.

\section{References}

1 Meriggioli MN, Sanders DB. Autoimmune myasthenia gravis: emerging clinical and biological heterogeneity. Lancet Neurol. 2009 May;8(5):475-90.

2 Béhin A, Mayer M, Kassis-Makhoul B, Jugie M, Espil-Taris C, Ferrer X, et al. Severe neonatal myasthenia due to maternal anti-MuSK antibodies. Neuromuscul Disord. 2008 Jun;18(6):443-6.

3 Hibi Y, Yasuno T, Okano S. Case report of a neonate born to the mother with anti-MuSK antibodies. Jpn Soc Perin Neon Med. 2007;43:127-30.

4 Neves AR, Monteiro P, Matos A, Santos Silva I. Anti-MuSK-positive myasthenia gravis diagnosed during pregnancy: new challenges for an old disease? BMJ Case Rep. 2015 Jan;2015 jan05 1:bcr2014207708.

5 Plauché WC. Myasthenia gravis in mothers and their newborns. Clin Obstet Gynecol. 1991 Mar;34(1):82-99.

6 Niks EH, Verrips A, Semmekrot BA, Prick MJ, Vincent A, van Tol MJ, et al. A transient neonatal myasthenic syndrome with anti-musk antibodies. Neurology. 2008 Apr;70(14):1215-6.

7 O'carroll P, Bertorini TE, Jacob G, Mitchell CW, Graff J. Transient neonatal myasthenia gravis in a baby born to a mother with new-onset anti-MuSK-mediated myasthenia gravis. J Clin Neuromuscul Dis. 2009 Dec;11(2):69-71.

8 Kanzaki A, Motomura M. [A pregnant patient with anti-MuSK antibody positive myasthenia gravis and her infant with transient neonatal myasthenia gravis]. Rinsho Shinkeigaku. 2011 Mar;51(3):188-91.

9 Lee JY, Min JH, Han SH, Han J. Transient neonatal myasthenia gravis due to a mother with ocular onset of anti-muscle specific kinase myasthenia gravis. Neuromuscul Disord. 2017 Jul;27(7):655-7.

10 Takahashi Y, Yamashita T, Morihara R, Nakano Y, Sato K, Takemoto M, et al. Emergency Caesarean section saved both an anti-MuSK antibody-positive myasthenia gravis mother with pregnancy-induced hypertension and her premature baby. Intern Med. 2017 Dec;56(24):3361-4.

11 Konishi T, Kousaka M, Yamakawa K, Matsui M, Ohta K. [Effects of acetylcholinesterase inhibitors on patients with MuSK antibody positive myasthenia gravis]. Rinsho Shinkeigaku. 2009 Oct;49(10):660-3.

12 Yilmaz V, Oflazer P, Aysal F, Durmus H, Poulas K, Yentur SP, et al. Differential cytokine changes in patients with myasthenia gravis with antibodies against AChR and MuSK. PLoS One. 2015 Apr;10(4):e0123546.

13 Ulusoy C, Kim E, Tüzün E, Huda R, Yllmaz V, Poulas K, et al. Preferential production of IgG1, IL-4 and IL-10 in MuSK-immunized mice. Clin Immunol. 2014 Apr;151(2):155-63.

14 Chatterjee P, Chiasson VL, Bounds KR, Mitchell BM. Regulation of the anti-inflammatory cytokines interleukin-4 and interleukin-10 during pregnancy. Front Immunol. 2014 May;5:253.

15 Lin A, Nutman T. IL-10 downregulates IL-4-induced IgE production through indirect effects on B cells. J Immunol 2017;198 (1 Supplement) 152.16. 


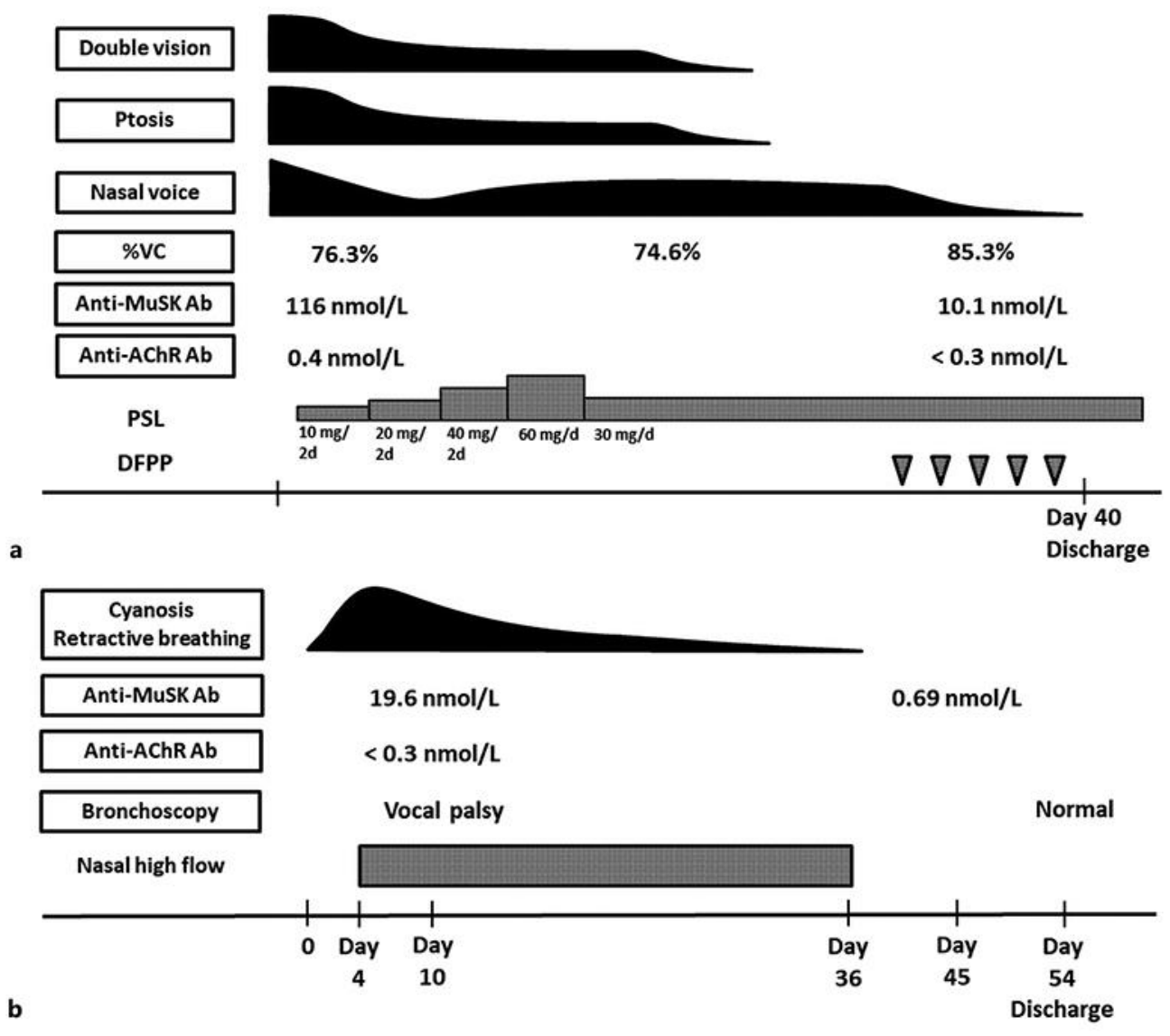

Fig. 1. a The clinical course of the mother. $\mathbf{b}$ The clinical course of the baby. 
Table 1. Demographics and clinical features of patients with myasthenia gravis carrying anti-muscle-specific tyrosine kinase antibody and their baby

\begin{tabular}{|c|c|c|c|c|c|c|c|c|c|}
\hline Case & First symptom & $\begin{array}{l}\text { Age at } \\
\text { pregnancy, } \\
\text { years }\end{array}$ & $\begin{array}{l}\text { Age at } \\
\text { diagnosis of } \\
\text { MuSK-MG, } \\
\text { years }\end{array}$ & $\begin{array}{l}\text { MG symptoms } \\
\text { during } \\
\text { pregnancy }\end{array}$ & $\begin{array}{l}\text { Treatment } \\
\text { during } \\
\text { pregnancy }\end{array}$ & $\begin{array}{l}\text { Pregnancy } \\
\text { history }\end{array}$ & $\begin{array}{l}\text { Baby } \\
\text { delivery/ } \\
\text { birth weight }\end{array}$ & $\begin{array}{l}\text { anti-MuSK } \\
\mathrm{Ab}\end{array}$ & symptoms \\
\hline $1[6]$ & $\begin{array}{l}13 \text { y bilateral ptosis, general } \\
\text { fatigue, bulbar palsy, neck } \\
\text { paresis }\end{array}$ & 24 & 23 & Steady & PSL $20 \mathrm{mg} / 2$ days & Miscarriage: 2 & $\begin{array}{l}38 \mathrm{w} 1 \mathrm{~d} / \\
3,190 \mathrm{~g}\end{array}$ & + & $\begin{array}{l}\text { Difficulty in drinking, } \\
\text { hypotonia, weak cry, } \\
\text { frog position }\end{array}$ \\
\hline 3 [7] & $\begin{array}{l}29 \text { y transient double vision, } \\
\text { general fatigue }\end{array}$ & 30 & $\begin{array}{l}30 \text { after } \\
\text { childbirth }\end{array}$ & $\begin{array}{l}\text { Worsened at } \\
\text { 2nd trimester }\end{array}$ & & Miscarriage: 1 & $\begin{array}{l}34 \mathrm{w}(\mathrm{CS}) / \\
\text { unknown }\end{array}$ & $\begin{array}{l}\text { Not } \\
\text { examined }\end{array}$ & $\begin{array}{l}\text { Floppy (ventilation, } \\
\text { IVIg) }\end{array}$ \\
\hline $4[3]$ & $25 \mathrm{y}$ bilateral ptosis & 34 & 32 & Steady & $\begin{array}{l}\text { Ambenonium, } \\
\text { chloride PSL } \\
20 \mathrm{mg}-10 \mathrm{mg}\end{array}$ & $\begin{array}{l}25 \text { y }(\mathrm{CS}) ; 1 \text { st } \\
\text { baby: normal }\end{array}$ & $\begin{array}{l}37 \text { w } 6 \mathrm{~d} \\
(\mathrm{CS}) / 2,558 \mathrm{~g}\end{array}$ & + & $\begin{array}{l}\text { Respiratory disturb- } \\
\text { ances, hypertonia of } \\
\text { lower limbs }\end{array}$ \\
\hline 6 [9] & $\begin{array}{l}27 \text { y (during pregnancy), } \\
\text { double vision }\end{array}$ & 27 & $\begin{array}{l}27 \text { after } \\
\text { childbirth }\end{array}$ & $\begin{array}{l}\text { Worsened at } \\
\text { 3rd trimester }\end{array}$ & $\begin{array}{l}\text { Pyridostigmine } \\
240 \mathrm{mg} / \text { day }\end{array}$ & & $\begin{array}{l}37 \text { w } 6 \mathrm{~d} \\
(\mathrm{CS}) / 2,740 \mathrm{~g}\end{array}$ & $\begin{array}{l}\text { Not } \\
\text { examined }\end{array}$ & $\begin{array}{l}\text { Hypotonia, respiratory } \\
\text { failure (ventilation) }\end{array}$ \\
\hline 7 [10] & $\begin{array}{l}43 \text { y double vision, bilateral } \\
\text { ptosis }\end{array}$ & 46 & $\begin{array}{l}46 \text { during } \\
\text { pregnancy }\end{array}$ & $\begin{array}{l}\text { Worsened at } \\
29 \text { weeks }\end{array}$ & PSL $10 \mathrm{mg} /$ day & & $\begin{array}{l}30 \mathrm{w} 5 \mathrm{~d} \\
(\mathrm{CS}) / 1,456 \mathrm{~g}\end{array}$ & + & $\begin{array}{l}\text { Respiratory failure } \\
\text { (ventilation) }\end{array}$ \\
\hline $8[4]$ & $\begin{array}{l}39 \text { y (during pregnancy), } \\
\text { bilateral ptosis, double vision, } \\
\text { dysphagia }\end{array}$ & 39 & $\begin{array}{l}39 \text { during } \\
\text { pregnancy }\end{array}$ & $\begin{array}{l}\text { Worsened at } \\
15 \text { and } 19 \text { weeks }\end{array}$ & $\begin{array}{l}\text { Pyridostigmine } \\
60 \mathrm{mg} / \text { day, mPSL } \\
64 \mathrm{mg} \text {, IVIg }\end{array}$ & $\begin{array}{l}\text { Miscarriage: } 2 \\
\text { (gravida: } 3 \text { ) }\end{array}$ & $\begin{array}{l}34 \mathrm{w} 4 \mathrm{~d} / \\
2,360 \mathrm{~g}\end{array}$ & $\begin{array}{l}\text { Not } \\
\text { examined }\end{array}$ & Without symptoms \\
\hline $\begin{array}{l}\text { Present } \\
\text { case }\end{array}$ & $\begin{array}{l}31 \text { y (during first pregnancy), } \\
\text { nasal voice }\end{array}$ & 34 & $\begin{array}{l}34 \text { after } \\
\text { childbirth }\end{array}$ & $\begin{array}{l}\text { Worsened at } \\
12 \text { weeks }\end{array}$ & Untreated & $\begin{array}{l}31 \text { y }(\mathrm{CS}) ; 1 \text { st } \\
\text { baby: respiratory } \\
\text { failure } \\
\text { Miscarriage: } 1\end{array}$ & $\begin{array}{l}37 \mathrm{w} 1 \mathrm{~d} \\
(\mathrm{CS}) / 2,617 \mathrm{~g}\end{array}$ & + & $\begin{array}{l}\text { Respiratory disturb- } \\
\text { ances, vocal cord } \\
\text { paralysis (nasal high } \\
\text { flow) }\end{array}$ \\
\hline
\end{tabular}

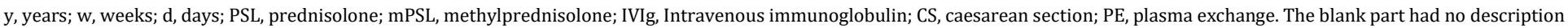
in the text. 